\title{
COVENANT WITH GOD AND THE MAKING OF THE EARLY CHRISTIAN MONASTICISM ${ }^{1}$
}

\section{Dmitrij F. Bumazhnov}

University of Göttingen, Collaborative Research Centre 1136:

"Education and Religion in Cultures of the Mediterranean and its Environment from Ancient to Medieval Times and to the Classical Islam",

Nikolausberger Weg 23, Göttingen, D-37073, Germany; bumazhnov@gmx.net

Starting from the second part of the $3^{\text {rd }}$ century A.D., a wide range of sources testifies to individual covenants which Christian ascetics or ascetic communities made with God. As it seems, at least three independent covenant traditions existed in Upper and Lower Egypt as well as in Syria/Mesopotamia. The function of those covenants was to provide theological basis for proto-monastic and early monastic groups appearing in those regions. Thus, the ascetic covenant theology seems to be one of the central ideas of the early monastic movement in its two most important centers - Syria and Egypt. Despite possible tensions with early Christian understanding of Church as New Israel being in a New Covenant with God, we do not have evidence that ascetic covenanters were opposing themselves to the Church. The rise of the covenant theology might have had to do with the so-called crisis of the $3^{\text {rd }}$ century. Refs 66 .

Keywords: early Christian monasticism, covenant with God, St. Antony, St. Pachomius, The Apocalypse of Elijah, Athanasius of Alexandria, Shenoute of Atripe.

In commemoration of my teacher Alexander I. Zaitsev

Forty years ago, Guerric Couilleau insightfully observed that the idea of a special covenant with God must have played a remarkable role during the earliest period of the development of the Egyptian monasticism. Couilleau illustrated his thesis by the so-called Letters of St. Antony ${ }^{2}$ and evidence from the Pachomian monastic tradition. In 2000, Vadim Lourié repeated and extended Couilleau's suggestion by further Pachomian evidence. ${ }^{3}$ In this study, I would like to present a number of other Christian proto-monastic and monastic texts from the $3^{\text {rd }}-4^{\text {th }}$ centuries where we find the same idea of a covenant with God into which a person or a group of persons enters. The purpose of this article is to show that similar covenant conceptions appeared independently from each other in various regions of the Mediterranean world beginning with the second part of the $3^{\text {rd }}$ century A.D. and became theological focus points for the developing monasticism.

Apart from the Letters of Antony and the Pachomian tradition, I have succeeded in identifying several new monastic sources with more or less developed covenant theology. With regard to the Letters, I was able to add some important instances different from those analysed by Couilleau and Lourié. It is this group of texts I would like to start with.

${ }^{1}$ I would like to thank Alexander Khosroyev and Alexander Bratuchin for their helpful suggestions.

2 Due to the influential book by Rubenson 1995, St. Antony the Great is generally acknowledged to be the author of the corpus of seven letters. See my criticism of Rubenson's thesis: Bumazhnov 2009, 83-88, $120-169$.

${ }^{3}$ Cf. Couilleau 1977 and Lourié 2000, 63-78.

(C) St. Petersburg State University, 2017 


\section{The so-called Letters of St. Antony}

As I hope I was able to show elsewhere, the corpus of the seven Letters widely thought to have been written by the father of the monks is not a work of one author. ${ }^{4}$ Whereas the first Letter can probably be regarded as going back to St. Antony, the remaining six were apparently produced by another early Egyptian monastic writer. ${ }^{5}$ If Samuel Rubenson is right in his dating, they "were written in the fourth or at latest the fifth decade of the fourth century". It is these six Letters in respect to which we can speak about a kind of covenant theology.

Differing from Couilleau and Lourié, who concentrated on the term "the law of the covenant" used several times in the Letters, ${ }^{7}$ I wish rather to call attention to the title "Israelites" six times applied to his correspondents by the author. ${ }^{8}$ In his understanding of this title, he is likely to follow Origen of Alexandria9 ( $†$ about 254) who uses "Israelites" as a designation of all members of the Church: ${ }^{10}$ on the one hand, they are part of the New Israel, the Church, on the other hand, they see (or know) Christ as God. ${ }^{11}$ The difference between Origen and the author of the Letters 2-7 is that the latter has in view not the whole Church but only a relatively small ascetic group he writes to. By implication, we can assume that this group, being Israel in the eyes of the author of the Letters, is thought to be - exactly as the people of the Old and New Testament (=covenant) in general - in a kind of a special covenant with God.

${ }^{4}$ See Bumazhnov 2009, 83-88.

5 Ibid. 120-169.

${ }^{6}$ Rubenson 1995, 45.

7 Couilleau 1977, 170-183, Lourié 2000, 55-62. The reconstruction of the original form and meaning of this term is a very complicated matter; see Rubenson 1995, 73-74, 197, n. 4 who does not come to an unambiguous conclusion. Since even the presence of the idea of a covenant in its original form is questionable I refrain here from detailed analysis of respective material. The problem needs further investigation.

${ }^{8}$ See ep. Ant. 5:1, 6:2, 6:78, 6:93, 7:5, 7:58a-b and Bumazhnov 2009, 106-108 for reconstructions of the original form of the title in all six instances. Since the Letters are transmitted in a number of versions (Coptic, Syriac, Old Georgian, Latin, and Arabic) I refer to them according to the English translation by Rubenson, 1995, 197-231 which has been made on the basis of all versions extant. Whether the original language of the Letters was Coptic (Rubenson 1995, 34) or Greek (Khosroyev 1995, 159) is disputed, see Bumazhnov 2009, 17 n. 82.

9 For general dependence of the remaining six Letters' on Origen's theology see Rubenson 1995, 37, 47, 60-68 and passim. For the title "Israelites" see Bumazhnov 2009, 114-117.

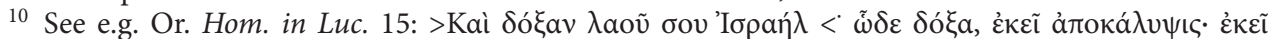

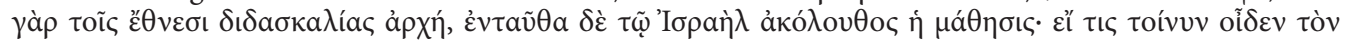

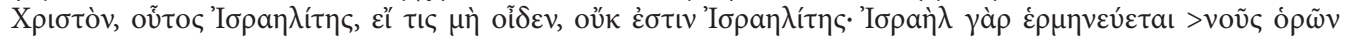
$\theta \varepsilon o ́ v<$. Rauer 1959, 106, 7-14. „, And the glory of your people Israel' (Lk 2:32). Here <is> 'glory', there revelation. Because there <lies the > beginning of instruction for the Gentiles, here - the following teaching for Israel: if someone has known Christ, he <is $>$ Israelite. If someone did not know $<$ Him $>$, he $<$ is $>$ not Israelite. For ,Israel" <means $>$ translated, mind seeing God"' Cf. ep. Ant. 3:6: "About your names in the flesh there is nothing to say; they will vanish. But if a man knows his true name he will also perceive the name of Truth. As long as he was struggling with the angel through the night Jacob was called Jacob, but when it dawned he was called Israel, which means ,a mind that sees God," Rubenson 1995, 206; for comparison of the three extant versions of this text see Bumazhnov 2009, 90-93. (Ps.?)-Antony wants to say that the true name of his correspondents is "Israelites". If not indicated otherwise all translations are mine.

${ }^{11}$ From the first century A.D., the (etymologically not correct) explanation of the name Israel as $\hat{\imath} \hat{s}$ $r \bar{a}$ 'â 'él, i.e. "man <who> saw God", and its derivatives were very widespread. In the Alexandrian tradition, to which Origen and the author of the Letters belonged, it can be found e.g. in Philon, De ebrietate 82: öparıv

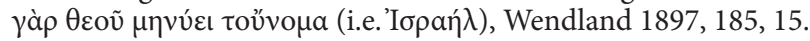




\section{The Covenant of St. Pachomius the Great}

The Pachomian evidence Vadim Lourié dealt with has to do with the feast of the remission of sins which the Pachomian koinonia celebrated in the month of Mesori (Copt. mĕsŏrē, corresponding roughly to August: August 7 to September 5). Lourié interprets it as a feast of the renewal of the covenant of St. Pachomius with God. ${ }^{12}$ In the $3^{\text {rd }}$ Sahidic Life of Pachomius the saint himself mentions this covenant (diathēke $<\delta ı \theta \eta \dot{\kappa} \uparrow) .{ }^{13}$ The context and some other similar places make clear that Pachomius entered into the covenant in order to reconcile God with human beings by means of his service to them in the name of God. God, for His part, committed Himself to preserving the spiritual seed of Pachomius (i.e. the Pachomian community) till the end of the world. ${ }^{14}$ We also find similar evidence about the covenant of the father of the community in other Pachomian sources. ${ }^{15}$ It is likely that this tradition goes back to Pachomius himself. If so, it has to be dated to around 313. ${ }^{16}$

The self-identification of the Pachomian community as Israel clearly has this individual covenant between God and St. Pachomius as its background. ${ }^{17}$ The covenant — as well as Pachomian traditions basing on it - do not seem to be connected with the socalled Letters of Antony and their notion of "Israelites". Whereas the Letters and their covenant theology demonstrate strong dependence on Origen, the respective Pachomian material is free from direct Alexandrian influences and can rather be compared with Biblical prototypes. ${ }^{18}$ Its roots are to be sought in the Christian, maybe partly Jewish-Christian traditions - very little known to us, it must be added - which Pachomius became acquainted with in the time after his conversion to Christianity.

\section{The Sons and Daughters of the Covenant}

Dealing with next examples of the covenant theology I will proceed chronologically. Probably the oldest one is to be found in Syria and Mesopotamia where sometime in the $3^{\text {rd }}$ or maybe even in the $2^{\text {nd }}$ century the term "sons and daughters of the covenant" (bnay qyāmā or respectively bnat qyāmā in Syriac) was coined. ${ }^{19}$ Our earliest clear evidence for this term is in the East Syrian Christian writer Aphrahat who lived in Mesopotamia in the first part of the $4^{\text {th }}$ century. The tradition concerning bnay/bnat qyāmā he uses seems however to be quite old. ${ }^{20}$ Some traces of it are recognisable in the Syriac Apology ${ }^{21}$ of

${ }^{12}$ Lourié 2000, 70-78, especially 77.

13 V. Pachom. S3 42b, Lefort 1952, 107b, 7-9: afrpměěwĕ ntdiathēkē ntafsmnts mnpnŏwte. "He recalled the covenant (diathēke $<\delta ı \theta \eta \dot{\kappa} \kappa \eta)$ which he had made with God." Words in round brackets indicate that the Coptic term was borrowed from the Greek.

14 See Couilleau 1977, 184-185 and De Pachomio et Theodoro paralipomena 18, Halkin 1932, 142, 1-3.

15 Couilleau 1977, ibid.

16 The secondary literature dealing with chronology of St. Pachomius' life is abundant; see e.g. Chitty 1954, Chitty 1957, Lorenz 1989, Joest 1994, Camplani 1995, Gould 1996, Gould 1997, Joest 2011.

${ }_{17}$ Lourié 2000, 64-78, especially 75-76.

${ }_{18}$ Lourié 2000, 76-77 refers e.g. to Jer 34:1-17.

19 Couilleau 1977, 190 briefly touches on this term. Some additions to his list of the scholarly investigations about it (Couilleau 1977, 190, n. 62) can be made; see Wensinck 1910, Koch 1911, Kittel 1915, Vööbus 1961, Nagel 1962. For less important contributions and articles published after Couilleau see Bumazhnov 2011a, 65-66.

20 See Vööbus 1951, 54.

21 About Syriac as original language of the Apology see Nöldeke 1887. 
Ps.-Meliton ${ }^{22}$ which, as some scholars argued, had been written in the beginning of the $3^{\text {rd }}$ century. ${ }^{23}$

The word qyāmā, a regular equivalent for "covenant" in the Syriac translations of the Bible, is derived from the root $q-w-m$, "to stand". Aphrahat uses it as designation of a group of ascetics who had taken a celibacy vow before baptism. ${ }^{24}$ In the Syriac texts after Aphrahat, bnay qyāmā and bnat qyāmā are for the most part equivalent to monks and nuns. As I suggested elsewhere, the original meaning of the Syriac term sons or daughters of the covenant has to do with standing firm before $\operatorname{God}^{25}$ and with being entirely absorbed in the doing His will. ${ }^{26}$ The idea of a special "covenant" between an ascetic and God was probably added secondarily and is due to the biblical usage of $q y \bar{a} m \bar{a}^{27}$ and to the baptismal context in which the celibacy vow was taken. ${ }^{28}$

This tradition is clearly different both from the covenant of St. Pachomius and the so-called Letters of Antony and seems to be older than they. A few important points of difference are that we, first, in this case, have to do with another region (Syria/Mesopotamia) and language (Syriac) which opens new possibilities in creating a distinct covenant theology. Secondly, our main source, Aphrahat, does not have any explicit terminology of the (New) Israel in connection with bnay/bnat qyāmā. Furthermore, though the covenant $(q y \bar{a} m \bar{a})$ is a personal one $e^{29}$ as in the case of St. Pachomius, it does not intend the foundation of an ascetic community deriving its legitimacy from the covenant of its father with God. Nor do we find any similarity between the celibacy vow of the sons or daughters of the covenant and the vow of Pachomius (see above) except for celibacy itself, which, however, is not explicitly mentioned in the Pachomian sources we possess. Lastly, the two Egyptian covenants do not demonstrate any recognisable connection with the baptism.

\section{The Apocalypse of Elijah}

The Christian Apocalypse of Elijah is transmitted in two Coptic versions: Achmimic and Sahidic. The Greek original of this text was written in Egypt, probably on the basis of an earlier Jewish Apocalypse, ${ }^{30}$ in the second part of the $3^{\text {rd }}$ century. ${ }^{31}$ In the chap-

22 See Bumazhnov 2011a, 69-73.

23 See Ulbrich 1906, 77. For discussion concerning the author of the Apology, see Bumazhnov 2011a, 69-70 n. 27.

24 See Nedungatt 1973, Griffith 1993, 145-153, and Griffith 1995, 229-234.

25 Standing before God is a widespread motive in the Bible and in the intertestamental literature, cf. 1 Kgs 17:1, 18:15, Sir 46:3 (the prophet Elijah), Deut 10:8; 18:5.7 (the Levites), Ex 19:17 (the Jewish people standing in front of Sinai during the revelation of God), and - most importantly — Dan 7:10 (heavenly Powers before the throne of God, cf. Lk 1:19, Rev 8:2, 2 Esdr 8:21, and 1 Enoch 39:12-13).

26 Bumazhnov 2011a, 81. For other explanations of bnay qyāmā and bnat qyāmā see ibid., 65-66.

27 I. e. in the sense "covenant"; being derived from the root $q-w-m$, "to stand", $q y \bar{a} m \bar{a}$ means primarily "standing firm", cf. Payne Smith 1998, s.v.

28 For connections between "standing" and baptism, see Murray 1975, especially 77-78 and Bumazhnov 2011a, 77, 80-81.

29 Occasionally, Aphrahat calls the whole Church qyāmā; Nedungatt 1973, 196-199 discusses all four instances. Regarding the relation between qyāmā as Church and bnay/bnat qyāmā as an ascetic group he concludes: "If the Church is a qyāmā, there is a qyāmā within that qyāmā", ibid., 200.

30 Cf. Schrage 1980, 204: "Allgemein wird die ApcEl für eine christlich überarbeitete jüdische Schrift gehalten".

31 For the dating see Schrage 1980, 201, 204-217, 220-225 and Frankfurter 1993, 17-20. The Greek original is lost. 
ter $1: 13^{32}$ the unknown author deals with the question of whether fasting is appropriate. He quotes a slogan of his adversaries: "The fast does not exist, nor did God create it"33 and contests it. In his view, people holding this opinion alienate themselves from the covenant (diathēke) of God. ${ }^{34}$ One can infer that the author and at least some part of his community were eager to maintain the covenant unbroken. The connection between fasting and covenant makes it probable that we have to do with a Christian ascetic proto-monastic group. ${ }^{35}$ In chapter 1:27, the author uses the popular Jewish-Christian imagery of an undivided heart. ${ }^{36}$ It might be therefore reasonably supposed that this group adapted some ideas that circulated in Egyptian Jewish-Christian milieu of the $3^{\text {rd }}$ century A.D. ${ }^{37}$

It is in this milieu that one has to search for the roots and exact meaning of the "covenant of God" 38 the author speaks about. Until this work is done, we shall have to be content with the intermediate conclusion that the Apocalypse of Elijah preserved an apparently independent covenant tradition. ${ }^{39}$

32 In chapter numeration, I follow the translation of Frankfurter 1993, 301-328.

33 Apok. El., Achmimic version = Sahidic version 1:13, English translation: Frankfurter 1993, 304. Achmimic text: Steindorff 1899, 70,2-3; Sahidic text: Pietersma 1981, 24, 3-4.

34 Apok. El., Achmimic version = Sahidic version 1:13: "who make themselves like strangers to the covenant (diathēkē) of God" (cf. Eph 2:12, Ps 77:10); English translation: Frankfurter 1993, 304. Achmimic text: Steindorff 1899, 70,4; Sahidic text: Pietersma 1981, 24,5. For an insignificant difference between the two Coptic versions see Schrage 1980, 235, n.d.

35 Another characteristic mark of the group in question is its special relation to the angels. People of the Lord (i.e. probably those belonging to the group) "will go with the angels (aggĕlos < å $\gamma \gamma \varepsilon \lambda$ oc) to my (i. e. Lord's) city", Apok. El., Achmimic version = Sahidic version 1:10, English translation: Frankfurter 1993, 303. Achmimic text: Steindorff 1899, 70,5-6; Sahidic text: Pietersma 1981, 22,12-13. The sinners, on the contrary, will be hindered on this way by the Thrones (probably, the evil angels) "because the <good,

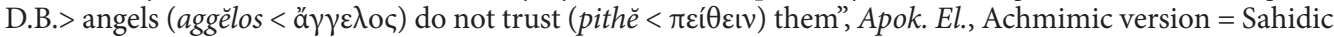
version 1:11, English translation: Frankfurter 1993, 303. Achmimic text: Steindorff 1899, 70,11, Sahidic text: Pietersma 1981, 22,16-17. Cf. also Apok. El., 18. 26. The close relationship of the believers with the angels has of course a long Christian prehistory (cf. e.g. Luk 20:35-36, Herm., Sim. 9,27,3, Herm. Vis. 2,2,2, Apocal. Iohan. apocryph. 25 (Tischendorf 91,1-5); I owe these parallels to Alexander L. Khosroyev), thus Apok. El. does not necessarily have to be interpreted in the light of later notion of monastic life as imitation of the bodiless state of the angels, cf. Frank 1964. But still, for the reconstruction of the historical milieu of the Apok. El., this parallel with later monasticism seems significant.

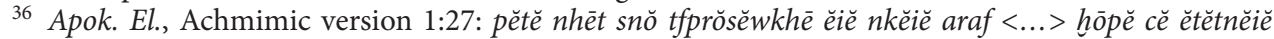
nŏwhèt nŏwōt nŏwaiš nim h̆m pčaěis "He who doubts (literally: "is <of> two hearts", cf. Ps 12:3 (LXX 11:3)

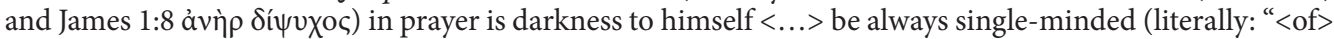
one heart") in the Lord", English translation: Frankfurter 1993, 305, Achmimic text: Steindorff 1899, 74, 8-12. Apok. El., Sahidic version 1:27: [p]ĕtŏ nhèt snaw hm těwprosĕwkhē [ĕfŏ] nkakĕ ĕrŏf < ...> ěšōpě cĕ ntĕtnŏ [nŏwh] èt nǒōt nnŏwǒěiš nim hm pčŏ[ěi]s "He who doubts (literally: "is <of> two hearts", cf. Crum 1939, 714 $a-b$ ) in prayer is darkness to himself $<\ldots>$ If, however, you are always single-minded (literally: "are $<$ of $>$ one heart") in the Lord <...>", English translation: Pietersma 1981, 27, 29, Sahidic text: Pietersma 1981, 28, 1-3. From the vast secondary literature on the Jewish and Christian concept of single-mindedness I refer here only to the three classical investigations: Edlund 1952, Amstutz 1968 and Guillaumont 1972.

37 Schrage 1980, 215 suggests that the unknown Jewish author of the Jewish Vorlage lived in Egypt, probably in Alexandria. Possible connections with Syriac sons and daughters of the covenant need further clarification.

${ }^{38}$ Cf. n. 34 above.

39 Though the extreme conciseness of the evidence precludes any far-reaching inferences, connections with Pachomian material appear more probable than in two other cases. Possibly links to the Syriac sons and daughters of the covenant likewise cannot be excluded. 


\section{Athanasius of Alexandria, Epistulae ad virgines (Coptic and Syriac)}

In the two Letters by St. Athanasius of Alexandria ( $† 373)$, both of which were probably entitled "To the virgins" and certainly composed in Greek, ${ }^{40}$ we find passages where the author mentions the covenant between virgins and God. In the Letter transmitted in Sahidic Coptic, Athanasius writes: “Think about your (pl.) vow, let your (pl.) goal (skŏpŏs

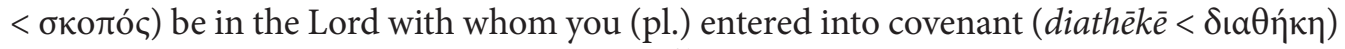
to remain virgins (parthĕnŏs $<\pi \alpha \rho \theta \varepsilon$ ćvo )." ${ }^{11}$ Athanasius says that now the virgins will no longer be called by their original names but everyone will call them "daughters of Jerusalem" ${ }^{42}$ This designation is to be compared with the title "Israelites" in the Letters of (Ps.?)-Antony. ${ }^{43}$ The two traditions concerning the change of names demonstrate obvious similarities and allow us to assume that they go back to a common Alexandrian source possibly related to Origen. ${ }^{44}$ In both cases a covenant theology is involved.

In the Syriac Epistula ad virgines ${ }^{45}$ Athanasius reproaches a virgin who seems to live in spiritual marriage with a $\operatorname{man}^{46}$ and reminds her of her covenant (Syr. qyāmā) with Christ: ${ }^{47}$ "Therefore, oh virgin, separate yourself from such love that separates you from the love of God! Dissolve your bond of favour ${ }^{48}$ towards a human being lest you should dissolve your covenant (Syr. qyāmā) with the celestial Bridegroom (i.e. Christ)." We do not know whether this particular virgin belonged to the group Athanasius writes to in the Coptic Epistula ad virgenes discussed above. The Syriac Letter testifies that, in the Egyptian communities of virgins Athanasius kept in touch with, the covenant theology was relatively widespread.

40 For general information about the Letters see Bumazhnov 2011b, 267-268.

41 Athan., ep. ad virg. (copt.): aripmĕěwĕ mpĕtnĕrēt marĕpĕtnskŏpŏs šōpĕ nētn ěhŏwn ĕpčŏěis pai ĕntatĕtnsmndiathēkē nmmaf ĕcō ĕtĕtnŏ mparthĕnŏs, Lefort 1955, 89, 36-90, 2. Martin 1996, 698-699 suggests that the Letter dates from the third exile of Athanasius in 356-360.

42 Athan., ep. ad virg. (copt.): ō nšěĕrĕ nthilèm, něwnamŏwtěcĕ an ěrōtn těnŏw ěbŏl hmpran nnĕntěiŏtĕ, alla ĕtbĕthĕ ěntatĕtnhōtr nmmaf ĕwnamŏwtĕ ěrōtn hitnŏwŏn nim čěnšěĕrĕ nthilēm, Lefort 1955, 92, 29-32. "Oh daughters of Jerusalem! You won't be called any more by the names of your parents. But, because of your joining yourselves to Him (i.e. Christ), everyone will call you ,daughters of Jerusalem." The appellation "daughters of Jerusalem" is an allusion to Song 2:7, 3:5 et al. "Joining to Christ" means, probably, taking celibacy vow or, using the terminology of the quotation in the $\mathrm{n}$. 41 above, entering the covenant with the Lord.

43 Ep. Ant. 5:1 provides a very close parallel to changing ascetics' names in spiritual ones: "Antony greets his beloved children, holy Israelite children, in their spiritual essence. I do not need to call you by your names in the flesh, which are passing away, for you are Israelite children", Rubenson 1995, 212; for comparison of four extant versions of this text see Bumazhnov 2009, 92-93; cf. also ep. Ant. 3:6 quoted above, n. 10 .

44 Cf. the quotation from Origen's Commentary on the Gospel of Luke in n. 10 above. An important difference from Origen is that both "Israelites" in the ep. Ant. and "daughters of Jerusalem" in Athanasius are applied to a restrict group of ascetics, whereas Origen uses the title "Israelites" potentially for all believers in Christ, i.e. the Church.

45 "Nothing in the work indicates a precise date, but most of its parallels to genuine Athanasiana are to works written after Athanasius's second exile, which ended in 346”, Brakke 1994, 27.

46 In the early Christian tradition, two forms of the so-called spiritual marriage are known: communal life of ascetics of both sexes under the same roof and a relationship between a member of clergy and a woman living together in the same house. These practices were vigorously criticized starting with the middle of the $3^{\text {rd }}$ century both in the Church councils and in the writings of the Church fathers, cf. Achelis 1902, 12-20, de Labriolle 1921, and Clark 1986.

47 Athan., ep. ad virg. (syr.): 'rhqy hkyl btwlt' mn hwwb'dd'yk hn': hw dmn hwb' 'lhy' mrhq lky. šry 'swrky mn șbyn' tb' dṣyd brnš': dl' tšryn qymky dlwt htn 'šmyn', Lebon 1928, 184, 312-314.

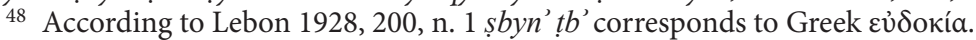




\section{Shenoute of Atripe}

Shenoute was an abbot of the White Monastery near Sohag in the Upper Egypt; he lived from c. 348 till $465 .{ }^{49}$ According to Johannes Leipoldt, it was Shenoute who introduced the solemn vow for the people who wanted to join his monastery. ${ }^{50}$ The Coptic text of this vow published by Leipoldt is entitled "Covenant" (diathēke $<\delta i \alpha \theta \eta \dot{\eta} \kappa \eta) .{ }^{51}$ The vow is concerned about discipline in the monastery and might be in a certain number of details different from the earlier formulas. ${ }^{52}$ Interestingly, Shenoute borrowed the idea of a vow to be taken by each monk becoming part of his congregation from an unknown elder and reflected long time on whether the vow is appropriate in his circumstances. ${ }^{53}$ Though this form of covenant says little about the beginning of monasticism, it is evident that it looked back on a more or less old tradition. No connections to the previous forms of monastic covenants can be recognized. ${ }^{54}$

\section{Historia monachorum in Aegypto}

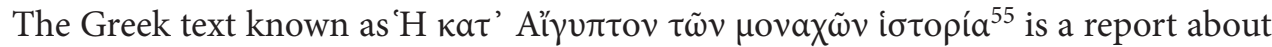
pilgrimage journey to the famous Egyptian ascetics that seven monks from Rufinus' of Aquileia monastery on the Mount of Olives in Jerusalem made in the winter 394/395. ${ }^{56}$ The text records two foundation stories concerning major monastic congregations which contain descriptions of what one can call making covenant between the founder of the congregation and God. The term "covenant" is missing in both cases.

Three common features of these descriptions can be stressed. First, the two saints in question - abba Or (hist. mon. 2) and abba Apollo (hist. mon. 8) - lived in Thebaid, in

49 About Shenoute's chronology see Cristea 2011, 111-122; about his works see Baumeister 2002 and Emmel 2004.

50 See Leipoldt 1903, 106-110 and Vita Sinuthii 99: "The angel said to him (i.e. to a repentant brother expelled from the White Monastery): 'If your father (i.e. Shenoute) were to receive you back again, will you

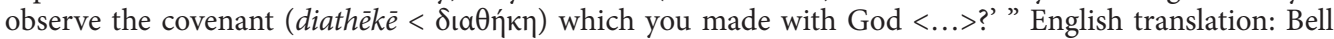
1983, 72, Bohairic text: Leipoldt 1951, 48, 27-29.

51 For the Coptic text see Leipoldt 1903, 195-196. The vow is transmitted as part of the Coptic text Leip. no. 53. Emmel 2004, 900-901 analyses the evidence and comes to the conclusion that "it cannot yet be entirely excluded that Shenoute is the author of Leip. no. 53, although this attribution does seem doubtful." The problem of the authorship of the vow is to be addressed separately. In this regard, Emmel is more optimistic, see Emmel 2004, 901, n.627.

52 I quote the vow in Leipoldt's German translation, Leipoldt 1903, 109: Gelübde (diathēk (sic) $<\delta ı \theta \eta \dot{\kappa} \eta)$. "Ich gelobe vor Gott an seinem heiligen Orte, indem das Wort, das ich mit meinem Munde gesprochen habe, Zeuge ist: ich will meinen Leib in keiner Weise beflecken; ich will nicht stehlen; ich will keinen Meineid schwören; ich will nicht lügen; ich will nicht heimlich Böses tun. Wenn ich übertrete, was ich gelobte, so will ich nicht ins Himmelreich kommen, obwohl ich es sah: Gott, vor dem ich die Bundesformel

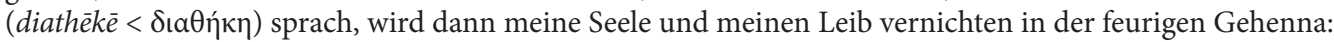
denn ich übertrat die Bundesformel (diathēke $<\delta ı \mid \theta \eta \dot{\kappa \eta}$ ), die ich sprach [...] Was aber den Widerspruch oder den Ungehorsam oder das Murren oder den Streit oder die Hartnäckigkeit und ähnliches betrifft, so weiß das die ganze Gemeinschaft."

${ }^{53}$ Leipoldt 1903, 108-109. This must have occurred shortly after Shenoute was chosen to succeed his uncle as the abbot of the White Monastery in 385, see Leipoldt 1903, 108 and Baumeister 2002, 622.

${ }^{54}$ Leipoldt 1903, 108 observes that, for introducing a novice vow, Shenoute did not have a Pachomian model.

${ }^{55}$ Historia monachorum in Aegypto is the title of Rufinus' of Aquileia Latin translation of this work made probably around 403/404 in Italy, see de Vogüé 1996, 317-320.

56 See Guillaumont 1991 and Skeb 2002. 
the Upper Egypt. ${ }^{57}$ Second, covenants with them were made after they had spent many years in the desert; the active part is taken by God or His angel. ${ }^{58}$ Third, the model for the two covenants is Abraham's covenant with God in Gen 12. In both cases God or, respectively, the angel promise that Or and Apollo will become fathers of great nation of monks. ${ }^{59}$

These two covenants are indisputably closely related to each other and represent the Upper Egypt covenant tradition which has some connections to the Pachomian material. ${ }^{60}$

\section{Related and independent covenant traditions}

The following table summarizes the covenant evidence presented above. The arrows indicate possible ways of influence or mutual connections. In cases of lesser certainty a question mark is added.

\begin{tabular}{|c|c|c|c|}
\hline Time & \multicolumn{2}{|l|}{ Egypt } & Syria/Mesopotamia \\
\hline $3^{\text {rd }}$ cent. & Apocalypse of Elijah & (?) & $\begin{array}{l}\text { Sons and daughters of the } \\
\text { covenant }\end{array}$ \\
\hline & Alexandria & Upper Egypt & \\
\hline after 313 & & $\begin{array}{l}\text { Pachomius (sources: } \\
\text { end of } 4^{\text {th }} \text { cent.) }\end{array}$ & \\
\hline $340-360$ & $\begin{array}{l}\text { (Origen, } \dagger \text { about 254) } \\
\text { Letters of (Ps.?)-Antony } \leftrightarrow \text { Athansius, } \\
\text { Ad virgines }\end{array}$ & & \\
\hline after 385 & & Shenoute & \\
\hline after 395 & & Historia monachorum & \\
\hline
\end{tabular}

57 See hist. mon. 2:1, Festugière 1971, 35,1 (Or); hist. mon. 8:1, Festugière 1971, 46, 2 (Apollo).

58 See hist. mon. 2:4: "When he (i.e. Or) had entered fully into old age, an angel appeared to him in the desert in a dream and said <...>"; English translation: Russell 1981, 63, Greek text: Festugière 1971, 36, 19-20. Hist. mon. 8:3: "When he (i.e. Apollo) was fifteen years old, he withdrew from the world and spent forty years in the desert $<\ldots>$ Then he seemed to hear the voice of God saying to him <...>; English translation: Russell 1981, 70, Greek text: Festugière 1971, 47, 18-21.

59 See hist. mon. 2:4: "You (i.e. Or) will be a great nation (Gen 12:2) and a numerous people will be entrusted to you. Those who will be saved through you will be ten myriads"; English translation: Russell

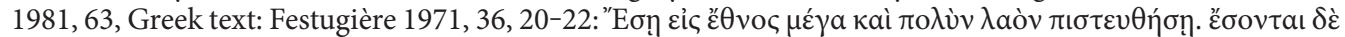

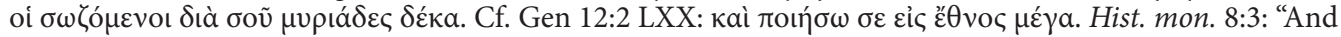
now make your way to the inhabited region, for you (i.e. Apollo) will bear me ,a peculiar people, zealous of good works' (Tit 2:14) "; English translation: Russell 1981, 70, Greek text: Festugière 1971, 47, 24-26: kaì võv

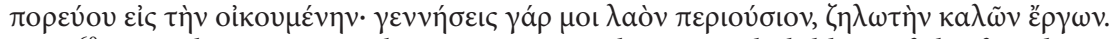

60 E.g. the covenant takes into account the spiritual children of the founder; cf. De Pachomio et Theodoro paralipomena 18, Halkin 1932, 142, 1-3, though the Pachomian sources do not demonstrate any direct connection to the covenant of Abraham. The covenant is transmitted through direct revelation by God or an angel; cf. Pachomii vita Sahidica $3\left(S^{3}\right)$, Lefort 1952, 106 B 35-107 B 23; Pachomii vita Graeca prima 23, Halkin 14, 20-25; Pachomii vita Bohairica 22, Lefort 1953, 21, 28-22, 10; but in the case of Pachomius the angel rather reminds the saint of the covenant already made between God and him. Differently from the Historia monachorum, Pachomius makes his covenant before becoming a monk and even a Christian; as it seems, it is he who takes the initiative in making a covenant; cf. Pach. v. Gr. pr. 5, Halkin 1932, 3, 27-4, 3; Pach. v. Boh. 7, Lefort 1953, 5, 5-10. The difference between making a covenant after many years of ascetic straggle in the desert (Or, Apollo) or in the very beginning of one's monastic career (Pachomius) can probably be explained by the fact that $O r$ and Apollo represent a later tradition in which making a covenant with God was regarded as presupposing certain ascetic achievements. 
The table demonstrates that we can speak about several more or less independent covenant traditions in Egypt two main of them being the Alexandrian and that of the Upper Egypt. So far, no clear connections between Egyptian and Syriac traditions have been found. A certain possibility of those connections cannot be completely excluded in the case of the Apocalypse of Elijah.

\section{Conclusion}

The idea of a personal or collective covenant with God appears independently in Syria/Mesopotamia and Egypt in the $3^{\text {rd }}-4^{\text {th }}$ century. In Egypt, we find various traditions of the covenant that seem to go back to different sources. Theologically, the idea of the covenant is one of the most important and currently much neglected building blocks in the process of the making of the early Christian monasticism. The participants in the covenant create a new relationship with God without, on the other hand, having to abolish their relationship with the Church. In other words, the personal covenant does not make the New Covenant invalid, though indirectly questions its efficiency in other Christian groups. The need for a new, more personal relationship with God in several Christian groups at the same time signalises that, towards the end of the $3^{\text {rd }}$ century, an immense shift from the collective to the individual understanding of Christianity had taken place. The dynamics and the reasons for that shift is a theme for further investigations. ${ }^{61}$

\section{References}

Achelis H. Virgines subintroductae. Ein Beitrag zu I Kor. VII. Leipzig, Hinrich, 1902.

Alföldy G. Historisches Bewußtsein während der Krise des 3. Jahrhunderts, in: G. Alföldy (Hg.) Krisen in der Antike: Bewußtsein und Bewältigung. Düsseldorf, Verlag Schann, 1975, 112-132.

Amstutz J. АП ОТТ $\Sigma$. Eine begriffsgeschichtliche Studie zum jüdisch-christlichen Griechisch. Bonn, Hanstein, 1968.

Baumeister T. Schenute von Atripe, in: S. Döpp, W. Geerlings (Hgg.), Lexikon der antiken christlichen Literatur. Freiburg, Herder, ${ }^{3} 2002,622-623$.

Bell D. N. (transl.) Besa, The Life of Shenoute. Kalamazoo, Michigan, Cistercian Publications, 1983.

Brakke D. The Authenticity of the Ascetic Athanasiana. Orientalia 1994, 63, 17-56.

Bumazhnov D. Visio mystica im Spannungsfeld frühchristlicher Überlieferungen. Die Lehre der sogenannten Antoniusbriefe von der Gottes- und Engelschau und das Problem unterschiedlicher spiritueller Traditionen im frühen ägyptischen Mönchtum. Tübingen, Mohr Siebeck, 2009.

Id. Qyāmā before Aphrahat. The Development of the Idea of Covenant in Some Early Syriac Documents, in: D. Bumazhnov, H. R. Seeliger (Hgg.) Syrien im 1.-7. Jahrhundert nach Christus. Akten der 1. Tübinger Tagung zum Christlichen Orient (15.-16. Juni 2007). Tübingen, Mohr Siebeck, 2011a, 65-81.

Id. Traktate zur weiblichen Askese, in: P.Gemeinhardt (Hg.), Athanasius Handbuch. Tübingen, Mohr Siebeck, 2011b, 265-271.

Chitty D. J. Pachomian Sources Reconsidered. Journal of Ecclesiastical History 1954, 5, 38-77.

Id. A Note on the Chronology of the Pachomian Foundations. Studia Patristica 1957, 2, 379-385.

Camplani A. Sulle date del sinodo di Latopolis e della morte di Pacomio. Studia Monastica 1995, 37, 7-17.

Clark E. A. John Chrysostom and the Subintroductae, in: ead. Ascetic Piety and Women's Faith: Essays on Late Ancient Christianity. Lewiston, Mellen, 1986, 265-290.

Couilleau G. L’ «alliance» aux origines du monachisme égyptien. Collectanea Cisterciensia 1977, 39, 170-193. Cristea H.-J. Schenute von Atripe: Contra Origenistas. Tübingen, Mohr Siebeck, 2011.

${ }^{61}$ As it seems, one of the reasons of those processes could have had to do with the so-called crisis of the $3^{\text {rd }}$ century. For this topic see Dodds 1965, Alföldy 1975, Piétri/Flamant/Gottlieb 2005. The list of the Greek, Coptic and Syriac evidence provided above does not raise the claim to be exhaustive. The further study of the subject should also take in account the Armenian evidence, cf. Shirinian 2001-2002 and Garsoïan, 2005-2007, 196, 202, 214, 216. 
Crum W.E. A Coptic Dictionary. Oxford, Clarendon Press, 1939.

Labriolle P. de. Le mariage spirituelle dans l’antiquité chrétienne. Revue historique 137, 1921, 204-225.

Vogüé A. de. Histoire littéraire du mouvement monastique dans l'antiquité, 3: Jérôme, Augustin et Rufin au tournant du siècle (391-405). Paris, Cerf, 1996.

Dodds E.R. Pagan and Christian in the Age of Anxiety: Some Aspects of Religious Experience from Marcus Aurelius to Constantine. Cambridge, Cambridge University Press, 1965.

Edlund C. Das Auge der Einfalt. Eine Untersuchung zu Matth. 6, 22-23 und Luk. 11, 34-35. Kopenhagen, Munksgaard, 1952.

Emmel S. Shenoute's Literary Corpus, 2 Vol., Louvain, Peeters, 2004.

Festugiére A.-J. (ed.), Historia monachorum in Aegypto. Édition critique du texte grec et traduction annotée. Bruxelles, Société des Bollandistes, 1971.

Frank K. S. АГГЕ $\Lambda$ IKO $В I O \Sigma$. Begriffsanalytische und begriffsgeschichtliche Untersuchung zum „Engelgleichen Leben" im frühen Mönchtum. Münster, Aschendorff, 1964.

Frankfurter D. Elijah in Upper Egypt. The Apocalypse of Elijah and Early Egyptian Christianity. Minneapolis, Fortress Press, 1993.

Garsoïan N. G. Introduction to the Problem of Early Armenian Monasticism. Revue des études arméiennes 2005-2007, 30, 177-236.

Griffith S. Monks, «Singles» and the «Sons of the Covenant». Reflections on Syriac Ascetic Terminology. Studia Anselmiana 1993, 110, 141-160.

Id. Asceticism in the Church of Syria: The Hermeneutics of Early Syrian Monasticism, in: V.L. Wimbush, R. Valantasis (eds.) Asceticism. New York - Oxford, Oxford University Press, 1995, 220-245.

Gould G. The Date of Pachomius' Death. Zeitschrift für die neutestamentliche Wissenschaft 1996, 87, 133137.

Id. Pachomian Sources Revised. Studia Patristica 1997, 30, 202-217.

Guillaumont A. Monachisme et éthique judéo-chrétienne. Recherches de Science Religieuse 1972, 60, 199-218; reprinted in: id. Aux origines du monachisme chrétien. Begrolle en Mauges, Abbaye de Bellefontaine, 1979, 201-218.

Id. Historia monachorum in Aegypto, in: A.S. Atiya (ed.) The Coptic Encyclopedia, vol. 4. New York, Macmillan 1991, 1237-1238.

Halkin F. (ed.) Sancti Pachomii Vitae Graecae. Bruxelles, Société des Bollandistes, 1932.

Joest Ch. Ein Versuch zur Chronologie Pachoms und Theodoros. Zeitschrift für die neutestamentliche Wissenschaft 1994, 85, 132-144.

Id. Erneute Erwägungen zur Chronologie Pachoms (287-347). Journal of Coptic Studies 2011, 13, 157-181.

Khosroyev A. Die Bibliothek von Nag Hammadi. Einige Probleme des Christentums in Ägypten während der ersten Jahrhunderte. Altenberge, Oros, 1995.

Kittel G. Eine synagogale Parallele zu den $\mathrm{B}^{\mathrm{e}}$ nai Q $\mathrm{Q}^{\mathrm{e}} \mathrm{jâmâ.} \mathrm{Zeitschrift} \mathrm{für} \mathrm{die} \mathrm{neutestamentliche} \mathrm{Wissenschaft}$ $1915,15,235-236$.

Koch H. Taufe und Askese in der alten ostsyrischen Kirche. Zeitschrift für die neutestamentliche Wissenschaft $1911,12,37-69$.

Lebon J. Athanasiana Syriaca II. Le Muséon 1928, 41, 169-216.

Lefort L.-Th. (ed.) S. Pachomii vitae Sahidice scriptae. Louvain, Durbecq, ${ }^{2} 1952$.

Id. (ed.) S. Pachomii vita Bohairice scripta. Louvain, Durbecq, 1953.

Id. (ed.) S. Athanase, Lettres festales et pastorals en copte. Louvain, Durbecq, 1955.

Leipoldt J. Schenute von Atripe und die Entstehung des national ägyptischen Christentums. Leipzig, Hinrichs'sche Buchhandlung, 1903.

Id. (ed.) Sinuthii Vita Bohairice. Louvain, Durbecq, 1951.

Lorenz R. Zur Chronologie des Pachomius. Zeitschrift für die neutestamentliche Wissenschaft 1989, 80, $280-$ 283.

Lourié V. M. Prizvanie Avraama. Idea monashestva i ee voploshchenie v Egipte. [The Calling of Abraham. The Idea of Monasticism and Its Realization in Egypt] St. Petersburg, Aleteja, 2000 (in Russian).

Martin A. Athanase d'Alexandrie et léglise d'Égypte au IV siècle (328-373). Roma, École Française de Rome, 1996.

Murray R. The Exhortation to Candidates for Ascetical Vows at Baptism in the Ancient Syriac Church. New Testament Studies 1975, 21, 59-80.

Nedungatt G. The Covenanters of the Early Syriac-Speaking Church. Orientalia Christiana Periodica 1973, 39, 191-215, 419-444.

Nagel P. Zum Problem der „Bundessöhne“ bei Afrahat. Forschungen und Fortschritte 1962, 36, 152-154. 
Nöldeke Th. Ueber die Apologie unter Meliton's Namen in Cureton's Spirilegium (sic) Syriacum. Jahrbücher für protestantische Theologie 1887, 13, 345-346.

Payne Smith J. A Compendious Syriac Dictionary founded upon the Thesaurus Syriacus of R. Payne Smith. Winona Lake, Indiana, Eisenbrauns, 1998; reprint of the $1^{\text {st }}$ edition, Oxford, Oxford University Press, 1903.

Pietersma A., Comstock S. T., Attridge, H.W. (ed.) The Apocalypse of Elijah based on P. Chester Beatty 2018. Chico, California, Scholars Press 1981.

Piétri L., Flamant J., Gottlieb G. Die Krise des Römischen Reiches und die Frage der Religion, in: Ch. Piétri, L. Pieétri (Hgg.) Das Entstehen der einen Christenheit (250-430). Freiburg, Herder, 2005, 3-22.

Rauer M. (ed.), Origenes Werke, Band IX. Die Homilien zu Lukas in der Übersetzung des Hieronymus und die griechischen Reste der Homilien und des Lukas-Kommentars. Berlin, Akademie-Verlag, ${ }^{2} 1959$.

Rubenson S. Letters of St. Antony. Monasticism and the Making of a Saint. Minneapolis, Fortress Press, ${ }^{2} 1995$.

Russell N. (trans.), The Lives of the Desert Fathers. The Historia monachorum in Aegypto. Kalamazoo, Michigan, Cistercian Publications, 1981.

Schrage W. Die Elia-Apokalypse. Gütersloh, Gerd Mohn, 1980.

Shirinian M.E. Reflections on the 'Sons and Daughters of the Covenant' in the Armenian Sources. Revue des études arméiennes 2001-2002, 28, 261-285.

Skeb M. Historia monachorum in Aegypto, in: S. Döpp, W. Geerlings (eds.) Lexikon der antiken christlichen Literatur. Freiburg et al., Herder, ${ }^{3} 2002,339-340$.

Steindorff G. (Hg.) Die Apokalypse des Elias. Eine unbekannte Apokalypse und Bruchstücke der SophoniasApokalypse. Koptische Texte, Übersetzung, Glossar. Leipzig, Hinrichs'sche Buchhandlung, 1899.

Tischendorf C. (ed.) Apocalypses apocryphae Mosis, Esdrae, Pauli, Iohannis, item Mariae Dormitio, additis evangeliorum et actuum apocryphorum supplementis. Lipsiae, Hermann Mendelssohn, 1866.

Ulbrich Th. Die pseudo-melitonische Apologie. Kirchengeschichtliche Abhandlungen 1906, 4, 67-148.

Vööbus A. Celibacy, a Requirement for Admission to Baptism in the Early Syrian Church. Stockholm, Estonian Theological Society in Exile, 1951.

Id. The Institution of the benai qeiama and benat qeiama in the Ancient Syrian Church. Church History 1961, 30, 19-27.

Wendland P. (ed.) Philonis Alexandrini opera quae supersunt. Vol. 2. Berolini, Georgii Reimeri, 1897.

Wensinck A.J. Qejāmā und Benai Qejāmā in der älteren Syrischen Literatur. Zeitschrift der Deutschen Morgenländischen Gesellschaft 1910, 64, 561-564, 812.

For citation: Dmitrij F. Bumazhnov. Covenant with God and the Making of the Early Christian Monasticism. Philologia Classica 2017, 12(1), 12-22. DOI: 10.21638/11701/spbu20.2017.102.

\section{ЗАВЕТ С БОГОМ И ФОРМИРОВАНИЕ РАННЕХРИСТИАНСКОГО МОНАШЕСТВА}

\section{Дмитрий Фёдорович Бумажнов}

Начиная со второй половины III в. от Р.Х. в различных регионах Египта, а также в Сирии и в Месопотамии начинают формироваться независимые друг от друга христианские традиции индивидуального завета, заключаемого между Богом и аскетом или аскетами. В большинстве известных случаев на основе этих заветов возникают аскетические протомонашеские и монашеские сообщества, часто понимающие самих себя как Израиль. Богословие аскетического завета, таким образом, выступает как одна из ведущих идей, формирующих раннее монашеское движение. Эта идея находилась в некотором противоречии с раннехристианским коллективизмом, а также с концепцией Нового Завета и самопониманием Церкви как Нового Израиля, однако не вела к открытому противопоставлению аскетов и Церкви. Истоки идеи аскетического завета, возможно, отчасти связаны с так называемым кризисом III в. Библиогр. 66 назв.

Ключевые слова: монашество, завет, Послания св. Антония, св. Пахомий, Апокалипсис Илии, св. Афанасий Александрийский, Афраат, сыны и дочери завета, Шенуте, История египетских монахов. 